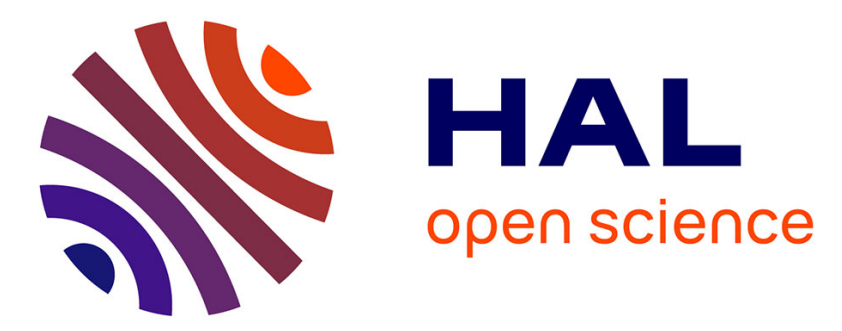

\title{
Influence of hydrodynamic connectivity on the genetic structure and gene flow of the common pandora Pagellus erythrinus
}

Anna Rita Rossi, Paolo Colangelo, L. Berline, Elisa Angiulli, Giandomenico

Ardizzone, Chiheb Fassatoui, Luciana Sola

\section{To cite this version:}

Anna Rita Rossi, Paolo Colangelo, L. Berline, Elisa Angiulli, Giandomenico Ardizzone, et al.. Influence of hydrodynamic connectivity on the genetic structure and gene flow of the common pandora Pagellus erythrinus. Hydrobiologia, 2019, 834 (1), pp.103-117. 10.1007/s10750-019-3914-y • hal-03016156

\section{HAL Id: hal-03016156 https://hal.science/hal-03016156}

Submitted on 20 Nov 2020

HAL is a multi-disciplinary open access archive for the deposit and dissemination of scientific research documents, whether they are published or not. The documents may come from teaching and research institutions in France or abroad, or from public or private research centers.
L'archive ouverte pluridisciplinaire HAL, est destinée au dépôt et à la diffusion de documents scientifiques de niveau recherche, publiés ou non, émanant des établissements d'enseignement et de recherche français ou étrangers, des laboratoires publics ou privés. 
1 Influence of hydrodynamic connectivity on the genetic structure and

2 gene flow of the common pandora Pagellus erythrinus

3

4 Anna Rita Rossi ${ }^{1}$, Paolo Colangelo ${ }^{1,5,}$, Léo Berline ${ }^{2}$, Elisa Angiulli ${ }^{1}$,

5 Giandomenico Ardizzone ${ }^{3}$, Chiheb Fassatoui ${ }^{4}$, Luciana Sola ${ }^{1}$

6

$7 \quad{ }^{1}$ Department of Biology and Biotechnology "C. Darwin”, Sapienza University of Rome,

8 via Borelli 50, 00161 Rome, Italy

92 Aix-Marseille Univ, Univ Toulon, CNRS, IRD, MIO UM 110, Mediterranean Institute of

10 Oceanography, Marseille, France

113 Department of Environmental Biology, Sapienza University of Rome, viale

12 dell'Università 32, 00185 Rome, Italy

$13{ }^{4}$ Ecosystems and Aquatic Resources Research Unit (UR13AGRO1), National Agronomy

14 Institute of Tunisia (INAT), University of Carthage, Charles Nicolle Avenue 43, 1082

15 Tunis, Tunisia

$16{ }^{5}$ National Research Council, CNR-IRET, Via Salaria km 29.300, 00015 Monterotondo

17 (Rome), Italy.

18

$19 *$ Corresponding author:

20 Paolo Colangelo

21 National Research Council, Via Salaria km 29.300, 00015 Monterotondo (Rome), Italy.

$22 \mathrm{c} / \mathrm{o}$

23 Department of Biology and Biotechnology “C. Darwin”, Sapienza University of Rome, via

24 Borelli 50, 00161 Rome, Italy

25 e-mail: paolo.colangelo@uniroma1.it

26 Telephone: +390649918122

27 Fax: +39064457516

28

29 Running title: Genetic structure of common pandora 


\section{ABSTRACT}

31 Many marine organisms have complex genetic patterns that cannot be easily

32 resolved by data analysis on spatial distribution of variability usually

33 applied in population genetic studies. We propose an analytical framework

34 to evaluate the role of dispersal during early life stages that considers the

35 actual hydrodynamic connectivity in the Mediterranean Sea, as a factor

36 shaping the population structure of demersal fishes. To this purpose, and to

37 test different scenarios of gene flow, genotypes of individuals of Pagellus

38 erythrinus sampled at 12 sites in the central Mediterranean Sea were

39 analyzed at ten microsatellite loci. The results show the lack of genetic

40 structure in western Mediterranean basin and a pattern of gene flow that

41 deviates from an isolation by distance model. The observed gene flow

42 estimates appear to be scale-dependent. At local scale, it is likely the result

43 of multifactorial components whereas at a larger scale it is mainly driven by

44 the sea currents, directly influencing dispersal of larvae between sites not

45 reachable by adult movements. Our results stress the importance of a 46 quantitative analysis of potential early life stage dispersal in any study

47 focusing on the population structure of fishes with a long larval stage.

49 KEYWORDS: demersal, dispersal, marine fishes, microsatellite, Sparidae, 50 oceanic circulation 


\section{INTRODUCTION}

52 Because of the absence of evident and pronounced physical barriers, the

53 marine environment has long been considered an open environment with

54 high potential species dispersal that prevents population subdivision (Hauser

$55 \&$ Carvalho, 2008). However, many studies have provided evidence

56 contrary to this hypothesis, i.e. the existence of pronounced population

57 structures even on a limited spatial scale in vagile species (Knutsen et al.,

58 2003; Ovenden at al., 2004; Palero et al., 2008; Ciannelli et al., 2010),

59 indicating a substantial gap between expectation and observation in marine

60 population genetics (Hedgecock \& Pudovkin, 2011). Indeed, both biotic

61 (including dispersal ability in different life stages, i.e. adults, juveniles,

62 larvae and eggs) and abiotic (historical and oceanographic) factors

63 components contribute to shape the genetic structure of marine species.

64 Among the biotic factors that are related to dispersal ability, the existence of

65 a pelagic larval phase is considered to play a key role in population

66 connectivity and to be the primary dispersal phase in benthic, demersal and

67 most coastal marine species (Cowen \& Sponaugle, 2009). As an example

68 planktonic larval duration (PLD), i.e. the amount of time that pelagic larvae

69 spend in the open sea before settlement, was supposed to be a good

70 predictor of the species' population connectivity and structure. However

71 discordant results were obtained among taxa when this hypothesis was

72 tested (see Bohonak, 1999; Jones et al., 2009; Weersing \& Toonen, 2009;

73 Kelly \& Palumbi, 2010; Riginos et al., 2011; Modica et al., 2017; Nanninga

74 \& Manica, 2018).

75 These evidences, and the absence of correlation between

$76 \mathrm{PDL} / \mathrm{dispersal} /$ genetic structure in multispecies studies reveals the 
77 complexity of the factors affecting population connectivity. Weersing \&

78 Toonen (2009) suggested that "larval biology of individual species, not

79 PLD, is likely the primary determinant of realized dispersal". This is

80 congruent with the idea that factors other than PLD drive population

81 connectivity (Félix-Hackradt et al., 2013) and define the distribution range

82 of fishes (Macpherson \& Raventos, 2006; Robitzch et al., 2016; Faillettaz et

83 al., 2018). As an example, within the Mediterranean Sea the effect of

84 oceanographic discontinuities, like currents and fronts, on genetic

85 differentiation is not homogenous on different species, and depends on their

86 life history traits (Pascual et al., 2017). Even more, in coral reef species,

87 larval biology is crucial in connectivity; it determines both the high

88 percentages of local self-recruitment (Swearer et al., 1999; Almany et al.,

89 2007), or the high levels of genetic connectivity across large geographic

90 scales (Horne et al., 2013; Simpson et al., 2014).

91 As far as the abiotc factors are concerned, oceanographic processes (often

92 not properly considered in studies on fish population genetics) can greatly

93 influence, or even determine, the connectivity of marine populations (White

94 et al., 2010; Schunter et al., 2011; Simpson et al., 2014). Therefore,

95 quantitative analyses of hydrodynamic connectivity, i.e. the exchange of

96 particles due to coastal and oceanic circulations at different spatial and

97 temporal scales, may represent a useful framework to interpret the current

98 genetic exchange patterns of a given species (Mitarai et al., 2009; White et

99 al., 2010; Berline et al., 2014). This, in turn, can provide useful information

100 to optimize management of commercially important fishes (Berry et al.,

101 2012). 
102 To date, a number of studies have effectively incorporated hydrodynamic

103 connectivity in population genetic research on various marine organisms,

104 using hydrodynamic models as proxy of passive dispersal. On this base

105 different models of seascape connectivity have been developed with the

106 main aims to (a) correlate historical and contemporary patterns of dispersal

107 among populations (see Riginos \& Liggins, 2013 for a review), (b)

108 recognize common patterns related both to egg type, larval features and

109 dispersal pathways (White et al., 2010; Crandall et al., 2012; Liggins et al.,

110 2016; Faillettaz et al., 2018), and (c) identify the biological and physical

111 drivers that shape genetic diversity (Simpson et al., 2014; Davies et al.,

112 2015; Liggins et al., 2016). These studies suggested that, at ecological time

113 scales, larval dispersal can show high variance and probably cover smaller

114 spatial scales than reported (Crandall et al., 2012) and that, in co-distributed

115 reef fishes, seascape features are better predictors of spatial genetic patterns

116 than dispersal traits (Liggins et al., 2016). Despite the application of a

117 variety of approaches (Jones et al., 2009), marine dispersal kernels remain

118 still largely undescribed. Here we tested the role of hydrodynamic

119 connectivity - (with different scenarios of gene flow) in determining the

120 observed pattern of the population genetic structure of a demersal fish, the

121 common pandora Pagellus erythrinus L. 1758.

122 The common pandora is a commercially important benthopelagic sparid fish

123 that inhabits inshore waters of the continental shelf of the northeastern

124 Atlantic Ocean, from Norway to Guinea-Bissau, and the Mediterranean and

125 Black Sea (Bauchot \& Hureau, 1986); it is present up to 200-300 m but

126 most commonly at 20-100 m and occasionally at 100-200 m (Busalacchi et

127 al., 2014). No catch in the 200-800 $\mathrm{m}$ stratum has been reported by the 
128 international bottom trawl survey in the Mediterranean (MEDITS, 2001).

129 The common pandora is a protogynous hermaphroditic fish that reproduces

130 during late spring and summer (Valdés et al., 2004), when adults migrate

131 from coastal waters to spawn in the open sea; trophic migration, in the

132 opposite direction, occurs in summer-autumn (Županović \& Jardas, 1989).

133 Eggs and larvae are pelagic; the median larval stage lasts 44 days and larvae

134 are distributed offshore (>1 mile) (Macpherson \& Raventos, 2006). The

135 species has a high commercial value and its catch has increased in the last

13630 years, particularly along the North African coast of the Mediterranean

137 Sea (FAO, 2018). It is also a candidate for marine fish aquaculture in the

138 Mediterranean Sea, and a small-scale production already exists in Greece

139 (Klaoudatos et al., 2004).

140 Previous mtDNA data (Angiulli et al., 2016) identified three sympatric

141 mitochondrial lineages in specimens collected at 15 sites in the

142 Mediterranean Sea and one in the Atlantic Ocean. The three lineages

143 probably originated from isolation and divergence processes and then came

144 into secondary contact during the Middle and Late Pleistocene glacial and

145 interglacial cycling (Angiulli et al., 2016). Within the central Mediterranean

146 Sea, their distribution does not show any evident geographic pattern,

147 suggesting high connectivity even across the putative boundaries between

148 the biogeographic sectors proposed in the investigated area (Villamor et al.,

149 2014), and between the two Tunisian sites where previous gene enzyme

150 electrophoresis analyses reported genetic differentiation (Fassatoui et al.,

$1512009,2011)$. The frequency distribution of mtDNA lineages across sampling

152 sites suggested a more limited matrilinear gene flow only between the

153 Mediterranean Sea and the Atlantic Ocean. 
154 According to the idea that nuclear loci should usually provide greater

155 resolution of genetic structure than mtDNA (Angers \& Bernatchez, 1998),

156 the main goal of this study was to analyze the present fine-scale population

157 structure and connectivity of P. erythrinus within the Mediterranean Sea and

158 to clarify the contribution of dispersal at different life history stages to

159 delineate this structure. For this purpose, we analyzed the genetic variation

160 at 10 microsatellite loci screened in specimens collected at 12 of the 16

161 sampling sites examined by mtDNA analysis (Angiulli et al., 2016). We

162 focused on the Italian and Tunisian sites and estimated the hydrodynamic

163 connectivity in the central Mediterranean Sea using a Lagrangian approach.

164 We assumed that (a) adult common pandora occupy bottoms of the

165 continental platform and are likely unable to move between sites separated

166 by deep stretches of sea, implying that their possible migration routes are

167 limited by the depth; (b) that eggs and larvae occupy superficial waters, as

168 larvae of Sparidae in the Mediterranean Sea are mainly concentrated in the

169 upper $10 \mathrm{~m}$ of the water column (Sabatés and Olivar, 1996). Thus, when

170 connectivity exists between two sites separated by a deep stretch of sea (>

$171300 \mathrm{~m}$ in depth), we might expect that it is due to pelagic larval migration of

172 early life history stages.

173 With this premise and on the base of the information derived from a

174 Lagrangian model of hydrodynamic connectivity, we tested different gene

175 flow scenarios in a Bayesian framework. In this way we aimed to determine

176 whether the identified genetic structure (i) can be attributed mainly to the

177 active dispersal capabilities of adults or (ii) is mainly shaped by early life

178 history dispersal between pairs of sites due to the effects of hydrodynamic

179 connectivity, or (iii) might be the result of both. 
MATERIALS AND METHODS

183

184 Sampling and microsatellite genotyping

185 Common pandora adults (Standard Length $>13 \mathrm{~cm}$ ) were collected from 12

186 sites along the Italian and Tunisian coasts in the Mediterranean Sea (Table 1,

187 Fig 1). The samples were collected during MEDITS (Mediterranean

188 International Trawl Survey, Bertrand et al., 2002) fishery research surveys

189 or were obtained from commercial fishing landings.

190 Pectoral fin clips were removed and preserved in $96 \%$ ethanol at $4^{\circ} \mathrm{C}$.

191 Voucher specimens were deposited in the Ichthyology Collection of the

192 Department of Biology and Biotechnology of Sapienza University of Rome

193 (ICDBB 970-974). Genomic DNA was extracted according to the procedure

194 of Aljanabi \& Martinez (1997) and then used as a template in polymerase

195 chain reactions (PCR) for 10 microsatellite loci expressly isolated for

196 Pagellus erythrinus (MS2, MS3, MS4, MS6, Ramsak et al., 2003) or for

197 other sparids (SL7, SL17, SL26, SL29 and SL33, Chopelet et al., 2009;

198 PbOviD102, Piñera et al., 2006). Loci were amplified in two multiplex

199 reactions in a total volume of $10 \mu \mathrm{l}$ containing $1 \mu \mathrm{l}$ of $10 \mathrm{x}$ buffer, $0.3 \mu \mathrm{l}$ of

$200 \mathrm{MgCl}_{2}(50 \mathrm{mM}), 0.2 \mu \mathrm{l}$ of $\operatorname{dNTP}(2.5 \mathrm{mM}), 0.1 \mu \mathrm{l}$ of each primer $(100 \mu \mathrm{M})$,

$2010.07 \mu 1$ of BIOTAQ ${ }^{\mathrm{TM}}$ DNA polymerase and 10-100 ng of DNA template.

202 The PCRs were performed in a Thermocycler T1 (Biometra, Göttingen,

203 Germany) with an initial denaturation of 2 min at $94^{\circ} \mathrm{C}$, followed by 40

204 cycles of $94^{\circ} \mathrm{C}$ for $30 \mathrm{~s}$, a locus-specific annealing temperature (for each

205 primer as described by the above-mentioned authors) for $45 \mathrm{~s}$ and $72{ }^{\circ} \mathrm{C}$ for 
$20630 \mathrm{~s}$ and a final extension at $72^{\circ} \mathrm{C}$ for $5 \mathrm{~min}$. PCR products were run on

$2076.5 \%$ denaturing polyacrylamide gel using a LI-COR DNA 4200 automated 208 sequencer (LI-COR Biosciences, Cambridge, UK). Allele sizes were 209 screened using GENE-IMAGE v4.05 software (Scanalytics, Fairfax, VA,

210 USA). Approximately $10 \%$ of the samples (50 individuals) were re-scored at

211 all 10 microsatellite loci to ensure repeatability.

\section{Data analysis}

\section{Genetic variability and differentiation}

215 Allele frequencies, expected and observed heterozygosity $\left(\mathrm{H}_{\exp }\right.$ and $\left.\mathrm{H}_{\mathrm{obs}}\right)$, 216 average number of alleles $(\mathrm{A})$, number of private alleles $\left(\mathrm{N}_{\mathrm{P}}\right)$ and allelic 217 richness $\left(A_{R}\right)$ were estimated per locus and per sampling site using 218 GENEPOP v3.4 (Raymond \& Rousset, 1995) and FSTAT v2.9.3.2 (Goudet, 219 2001) software. Deviation from Hardy-Weinberg equilibrium (HWE) and

220 linkage disequilibrium were tested for each locus and pairs of loci 221 respectively, and for sampling site. Statistical significance of both analyses 222 was calculated with the Markov Chain Monte Carlo (MCMC) method using $22310^{4}$ permutations, $5 \times 10^{3}$ dememorization steps and 500 batches. Sequential 224 false discovery rate (FDR) correction for multiple tests was applied for the 225 HWE tests and for the linkage disequilibrium significance because of the 226 large number of tests involved (Benjamini \& Hochberg, 1995).

227 The occurrence of putative null alleles, large allele drop-out and scoring 228 errors was evaluated using MICROCHECKER (Van Oosterhout et al., 229 2004). Moreover, the frequency of null alleles was tested using the

230 Expectation Maximization algorithm of Dempster et al., (1977), 231 implemented in FreeNA software (Chapuis \& Estoup, 2007). 
232 The presence of loci under selection was evaluated by the coalescent 233 approach (Beaumont \& Nichols, 1996) and by both a global outlier test, 234 implemented in LOSITAN (Antao et al., 2008), and the hierarchical method 235 of Excoffier et al. (2009), using the software ARLEQUIN v3.5 (Excoffier \& 236 Lischer, 2010). The LOSITAN analyses were performed under the infinite 237 allele model (IAM) and the stepwise mutation model (SMM) with $95 \times 10^{3}$ 238 permutations and 99\% confidence interval, while the ARLEQUIN analyses

239 were carried out under a hierarchical island model with $5 \times 10^{4}$ coalescent 240 simulations.

241 Genetic differentiation between samples was tested by $F_{S T}$ (Weir \& 242 Cockerham, 1984) and $R_{S T}$ (Slatkin, 1995) using ARLEQUIN v3.5 and 243 RSTCALC v2.1 (Goodman, 1997) respectively, and the significance of 244 pairwise values was calculated with the MCMC method using $10^{4}$ 245 permutations, $5 \times 10^{3}$ dememorization steps and 500 batches. Sequential false 246 discovery rate (FDR) correction for multiple tests was applied.

247 The simulation-based program POWSIM v4.1 (Ryman \& Palm, 2006) was 248 used to assess the statistical power of the 10 microsatellite loci to detect 249 various levels of divergence among sampling sites. The simulations were 250 performed using different combinations of $N_{e}$ (effective population size) and $251 t$ (time of divergence) leading to $F_{S T}$ values in the range $0.005-0.010$. The 252 tested values of $F_{S T}$ and $N_{e}$ were selected according to the estimated values 253 from data of this study (see Results section). The statistical power of the 254 dataset was evaluated using Chi-squared and Fisher's exact tests. The 255 estimate of power was reported as the proportion of significant outcomes $256(\mathrm{p}<0.05)$ after 1000 replicates.

257 The correlation between least cost geographic distances and the genetic 
258 distances, calculated as the $F_{S T} /\left(1-F_{S T}\right)$, was analyzed with a Mantel test,

259 using the software R statistical environment ( $\mathrm{R}$ Development Core Team,

260 2011). Least cost distances among pairs of sites were calculated using the

261 function shortest Path implemented in the "gdistance" package (van Etten,

262 2017). In order to obtain a least cost distance, we allowed connection only

263 through areas covered by sea, preventing connection across a land surface.

\section{Cluster analysis}

266 Bayesian cluster analysis implemented in STRUCTURE 2.3 (Pritchard et

267 al., 2000) was used to estimate the number of genetic clusters $(K)$ within the

268 dataset. Mean and variance of log likelihoods of the number of clusters for

$269 K=1$ to $K=12$ (the number of sampling sites) were inferred from multilocus

270 genotypes using the MCMC method. Twenty replicates for each set of

271 values of $K$ with $1.5 \times 10^{6}$ iterations (burn-in period of $1 \times 10^{5}$ iterations) were

272 performed under the admixture ancestry model and the assumption of

273 correlated allele frequencies among samples (Falush et al., 2003).

274 In addition to STRUCTURE, discriminant analysis of principal components

275 (DAPC; Jombart et al., 2010) was used to detect the best number of genetic

276 clusters using the function find.cluster. The correct number of clusters (K)

277 was determined by testing $\mathrm{K}$ values from 1 to 12 . Different clustering

278 solutions were then compared using Bayesian Information Criterion (BIC).

279 Subsequently DAPC was performed (the first 100 PC scores, which account

280 for $80 \%$ of the total cumulative variance, were retained) to evaluate the

281 percentage of posterior correct assignments. Both K-means and DAPC were

282 implemented in the R package adegenet v1.3-1 (Jombart, 2008; Jombart \&

283 Ahmed, 2011). 


\section{Hydrodynamic model}

286 A Lagrangian approach was used to quantify hydrodynamic connectivity.

287 We define Oceanic distances (OD) as the mean connection time (MCT)

288 taken by particles to connect two sites. The dispersal of a large ensemble of

289 passive particles by the oceanic circulation was modeled using currents

290 from a multiannual realistic ocean model simulation covering the whole

291 Mediterranean basin. Particles were released in the surface layer $(0-100 \mathrm{~m})$

292 where eggs and larvae are generally found (Klimogianni et al., 2004 and

293 references therein). For each pair of square sub-regions of $50 \mathrm{~km}$ per side,

294 the time needed to go from one sub-region to the other (by the particles) was

295 computed. The average time to connect site pairs found in a specific sub-

296 region provides a measure of the oceanic distance. The resulting MCT

297 matrix is asymmetric since the time required by a particle to go from site

298 "a" to site "b" is not equal to the time to go from "b" to "a". Details of the

299 method and how to calculate MCT can be found in Berline et al. (2014).

300 Here we only consider MCT below 200 days, a time window that includes

301 the embryonic and larval phases as well as the early juvenile stage. The

302 pairwise hydrodynamic connectivity was then used to propose different

303 dispersal scenarios of gene flow (see below).

305 Gene flow and hydrodynamic connectivity

306 Gene flow within the Mediterranean Sea was estimated using a coalescent

307 based approach implemented in MIGRATE-N v3.6 (Beerli \& Felsenstein,

308 2001; Beerli, 2006), and alternative migration hypotheses (Beerli \&

309 Palczewski, 2010) were tested. 
310 Complete panmixia (Fig. 2, Model 0: all the sampled specimens belong to a

311 unique large panmictic unit) was tested versus seven alternative migration

312 models (Fig. 2, Models 1-7). The evaluated scenarios allowed us to test

313 alternative population structures and migration dynamics (adults and early

314 life history dispersal) along different routes.

315 In the first migration model (Fig. 2: Model 1), sampled populations were

316 pooled according to their geographic sea origin: Ligurian Sea, Tyrrhenian

317 Sea, Sea of Sardinia, Sicilian Channel, Ionian Sea, Adriatic Sea. Migration

318 rates were allowed to be bi-directional between pairs of adjacent seas. All

319 the successive models considered the sampled geographic populations as

320 distinct genetic units, whereas migration rates among them were evaluated

321 according to different schemes. Indeed, in the second migration model (Fig.

322 2: Model 2) the gene flow was considered a bi-directional stepping stone

323 process related to active dispersal of $P$. erythrinus. Thus, the gene flow was

324 estimated only between sites whose distances and path could be covered by

325 adult migration routes along coastlines or across sea stretches less than 300

326 m deep.

327 This model allowed us to identify three groups of sites that can exchange 328 migrants (Fig. 2: Model 2). In the subsequent model (Fig. 2: Model 3) we

329 extended the previous model by considering additional early life history

330 dispersal routes mediated by sea currents. On the basis of oceanic distances

331 (see hydrodynamic connectivity) we identified two routes that allowed us to

332 connect the three groups of Model 2, thus allowing a potential continuous

333 exchange of genes across the sampled sites. In more detail we identified the

334 two unidirectional routes (EN->SN and AL->BZ) that allowed an early life

335 history dispersal between the three groups of units with the shortest period 
336 (112 and 91 days respectively). These migration routes, identified on the

337 basis of the oceanic distances, are congruent with the oceanic circulation

338 known for the area (I.I.M., 1982; Millot \& Taupier-Letage, 2005; Berline et

339 al., 2014). In Models 4, 5 and 6 (Fig. 2) only a main effect of early life

340 history gene flow, mediated by oceanic circulation, was considered. In these

341 three models, different thresholds were used to calculate which localities are

342 connected by sea currents respectively up to 100,150 and 200 days. In these

343 models, migration routes could be uni-directional because in some cases the

344 adopted time thresholds allowed a particle to go from one locality to another

345 but not vice versa. Finally, a further model (Fig. 2: Model 7) was tested

346 considering all the sampled populations as independent genetic units; bi-

347 directional migration was possible among all pairs of sampling sites.

348 Initially, a number of preliminary runs, using all sites and assuming a full

349 migration matrix, was performed to identify the best parameters for the

350 search. Identification of the optimal MCMC parameters was done until

351 consecutive runs produced overlapping results and the estimated values for

352 all the parameters showed a normal distribution (i.e. no double peaks and

353 narrow intervals). The search parameters were then adopted for all the

354 models tested. Initial migration (M) parameters were estimated using $F_{S T}$.

355 Default MIGRATE-N priors were used for all the models. For each model

356 two independent multiple MCMCs were run for 1000000 steps, sampling

357 every 100 steps. For each MCMC chain the first 10000 trees were discarded

358 and a static heating scheme was adopted (4 chains with temperatures:

$3591000000,3,1.20,1)$. For each analysis the effective sample size (ESS) was

360 evaluated and it was found to be much higher than 1000 for all the

361 parameters in all the models tested, with the only exception for the most 
362 complex model ( $\mathrm{n}=144$ parameters) showing seven parameters with an ESS

363 slightly lower than 1000. The marginal likelihood of each model, as 364 obtained by Bezier approximation, was used to calculate the model 365 probability, estimated by dividing each marginal likelihood by the sum of

366 the marginal likelihoods of all used models.

367

\section{RESULTS}

369 In total, 470 common pandora individuals from 12 sampling sites (Table 1)

370 were screened for 10 microsatellite loci. The 50 DNA samples that were

371 amplified and scored twice produced identical results in each trial.

373 Genetic variability

374 Genetic variability parameters vary considerably among the 10 loci (Online 375 resource 1): MS6 is the locus with the lowest number of alleles (14 distinct 376 alleles, $\mathrm{A}=6.4$ ), while MS2 is the most variable (83 distinct alleles, $377 \mathrm{~A}=35.6$ ). Private alleles (65) constitute $14 \%$ of the total alleles (464), 378 ranging from $7.8 \%$ at locus SL17 to $35.3 \%$ at locus SL33. The number of 379 alleles per sampling site is medium/high and quite homogeneously 380 distributed across samples (A ranges from 22 to 25.4, Table 1). Private 381 allele distribution across sites ranges from $0.42 \%$ at sampling site LM to

$3823.75 \%$ at $\mathrm{AN}$. Levels of mean $\mathrm{H}_{\mathrm{obs}}$ are similar among all samples, ranging 383 from 0.748 to 0.802 , but lower than the $\mathrm{H}_{\exp }$ (Table 1 ).

384 Significant departures from HWE were observed in 50 of 120 locus/site 385 combinations after FDR correction (Online resource 2). MS2 and SL33 are 386 the most affected loci (Online resource 2). All deviations are characterized 387 by heterozygote deficit, and according to MICROCHECKER half of them 
388 are associated with the presence of putative null alleles, whose frequencies

389 in each locus are not uniformly distributed across different sampled

390 populations (Online resource 2). According to this, the deviation from HWE

391 due to heterozygote deficit observed in our dataset cannot be simply

392 explained by a widespread presence of null alleles but rather as the result of

393 a combination of factors including other biological processes (e.g.

394 inbreeding and/or the Wahlund effect). Indeed, heterozygote deficit and

395 positive $F_{I S}$ are also observed when data are calculated for each population

396 (data not shown). The different components that act on heterozygote deficit

397 cannot be easily discerned by a multilocus data analysis (Dharmarajan et al.,

398 2013). Carlsson (2008) demonstrated that the occurrence of null alleles

399 could only slightly affect the assignment test and $F_{S T}$ estimation. Moreover,

400 a conservative approach of discarding loci deviating from HWE

401 expectations could eliminate informative markers and thus affect the

402 inferences on biological phenomena derived from the data (Dharmarajan et

403 al., 2013). According to these considerations and to the non-uniform

404 frequency distribution of null alleles across different populations, we

405 retained one of the two most affected loci, MS2, in the analysis; the other

406 one, SL33, was excluded from the genetic structure analysis as it is also

407 under selection (see below).

408 No linkage disequilibrium was detected for each pair of loci (585 pairwise

409 comparisons) by the FDR method.

\section{Population structure}

412 The POWSIM analysis showed that the combination of microsatellite loci

413 and sample sizes rendered a statistical power sufficient to detect a low level 
414 of differentiation. In fact, about $95 \%\left(\chi^{2}\right)$ and more than $90 \%$ (Fisher's) of 415 the tests where the $\mathrm{N}_{\mathrm{e}} / \mathrm{t}$ combination led to $F_{S T}=0.0010$ and $100 \%$ (both $\chi^{2}$ 416 and Fisher's) of the tests where $\mathrm{N}_{\mathrm{e}} / \mathrm{t}$ led to a $F_{S T}$ value of $\geq 0.0025$ were 417 statistically significant (Online resource 3 ). The $F_{S T}$ values were significant 418 for all loci with the exception of PbOviD102. The global outlier test 419 revealed directional selection at one locus, SL33, using both LOSITAN ( $\mathrm{p}<$ 420 0.01) under IAM and SMM models and ARLEQUIN $(p<0.001)$. These 421 results suggested that SL33 is under positive selection, and for this reason 422 this locus was eliminated from subsequent analyses.

423 Multilocus $F_{S T}$ among all samples $=0.00395(\mathrm{p}<0.001)$. Multilocus pairwise 424 estimates of $F_{S T}$ and $R_{S T}$ are reported in Table 2. Only two pairwise 425 comparisons were found to be significant after FDR correction, AN-BA and 426 GA-BA, for $F_{S T}$ and $R_{S T}$, respectively.

427 The Mantel test applied to all sampling sites revealed the absence of 428 correlation between genetic distances, expressed as $F_{S T} /\left(1-F_{S T}\right)$, and 429 geographic distances $(\mathrm{z}=231132.8, \mathrm{p}=0.175)$.

\section{Cluster analysis}

433 Cluster analyses by means of STRUCTURE identified, among the 12 tested $434 \mathrm{~K}$, the greatest posterior probability value at $\mathrm{K}=1$, i.e. a single genetic 435 cluster.

436 In contrast, according to BIC the best number of clusters inferred by the k437 means analyses within the Mediterranean Sea sites is four, and DAPC 438 provided $>0.96 \%$ of posterior correct group assignments. The four genetic 439 clusters can be easily distinguished by the first two discriminant axes, and 
each includes a different number of individuals $(n=112,110,93$ and 121

441 respectively for cluster 1, 2, 3 and 4). All four clusters are not related to

442 specific geographic areas and were found at all the sampling sites (Fig. 3,

443 Online resource 4). Frequency of cluster across the twelve sites is not

444 significantly different according to chi-square test $(\mathrm{p}=0.08)$

\section{Gene flow and hydrodynamic connectivity}

447 Lagrangian model returns that only 59 possible connections (versus a total 448 of 144 hypothetical ones) can occur within the threshold of 200 days.

449 The MCTs range between a maximum of 199 days and a minimum of 53 450 days, with an average of 134 days. Shortest MCT were found between 451 Sardinian (SN-AL) and Tyrrhenian sites (GA-FM, FM-EN) as well as 452 between Jonian and southern Tyrrhenian sites (JO-VM).

453 As expected, the largest MCTs were found between sites located in different 454 sea basins. For every pair of sites, a strong asymmetry exists between the 455 two directions of transport (Online resource 5).

456 Among the different migration models, according to the marginal 457 likelihoods, the highest support (relative probability, $\mathrm{P}=1$ ) was obtained for 458 Model 3 (Online resource 6). All the estimated migration rates (M) show 459 narrow $95 \%$ confidence intervals with density distributions following a 460 normal distribution. Migration rates between pairs of sites are scattered 461 across a wide range of values and are summarized in Fig. 4a and b. 462 Estimated migration rates are almost symmetrical between all pairs of sites, 463 with the exception of FM<->EN and LM<->ZA (Fig 4a). The estimated 464 migration rates between pairs of sites (EN->SN and AL->BZ) that cannot be 465 reached by adult $P$. erythrinus are comparable or even higher than those 
466 observed between geographically adjacent pairs of sites that can be reached

467 by adult dispersal. Very low migration rates were observed among a few

468 sites and particularly characterized Adriatic (AN, BA) and Ionian (JO) sites.

\section{DISCUSSION}

\section{Population structure}

472 Our results highlight a lack of spatial population structure in the common 473 pandora, similar to what observed in other Mediterranean demersal species 474 (Schunter et al., 2011; Franchini et al., 2012). Partial inconsistencies among 475 results obtained by the different analysis/programs employed could derive 476 from the different assumptions on which the various methods rely, such as a 477 priori grouping of individuals or their assumed pure/mixed ancestry. As an 478 example, simulated data show that below $F_{\mathrm{ST}}=0.1$, STRUCTURE is unable 479 to correctly identify the number of subpopulations, providing false certainty 480 regarding the $\mathrm{K}$ (Latch et al., 2006).

481 STRUCTURE suggests potential panmixia in the common pandora whereas

482 this scenario, that consider random genetic exchange among individuals and 483 population with the same probability, is rejected by the MIGRATE-N model 484 comparison. The k-means clustering and DAPC methods identify four 485 different genetic clusters (Online resource 4), which however are spread 486 across all sites and thus fail to identify a spatial structuring of genetic 487 diversity. A previous mtDNA sequence analysis of the same samples within 488 the Mediterranean Sea depicted a similar pattern characterized by the 489 absence of a spatial genetic structure (Angiulli et al., 2016). Due to their

490 different mutation rates and uni- or bi-parental inheritance, mitochondrial 491 DNA and microsatellites usually provide different sensitivities at different 
492 temporal scales. Mitochondrial DNA is more suitable to record signatures of

493 historical processes (Avise, 2000), related to the last few million years.

494 Microsatellites perform better in unraveling contemporary and recent 495 processes, i.e. occurring in the last 10 thousand years (Hewitt, 2004). The 496 advance of combining of the two kind of markers has been proved in marine 497 fishes (Limborg et al., 2012), although sometimes they can yield different 498 results, i.e. identify, different numbers of subpopulations (Durand et al., 499 2013; Lemos et al., 2005; Sala-Bozano et al., 2009; Silva et al., 2014). In the 500 common pandora mtDNA and microsatellites provide similar pattern of 501 genetic diversity with differentiated genetic clusters, occurring in sympatry.

502 This pattern could be explained by group differentiation due to vicariance 503 events, with the groups subsequently entering into secondary contact once 504 the disappearance of putative barriers permitted complete connectivity in the 505 Mediterranean basin.

\section{Impact of hydrodynamic connectivity on gene flow pattern}

508 Knowledge of the influence of hydrodynamic patterns on population 509 connectivity of many Mediterranean species is still scarce, whereas it could 510 be particularly important for the study of the genetic structure of demersal 511 fishes. In these species, adults are usually associated with benthonic 512 environments and, although capable of long-distance dispersion, are limited 513 in crossing deep sea stretches, that act as natural barriers. As a consequence, 514 long-range dispersal cannot be attributed to adult movements alone, but 515 rather also to what occurs during the earliest ontogenetic stages, when eggs 516 and larvae are dispersed by sea currents.

517 We employed an analytical method that allowed us to gain insight into the 
518 gene flow and connectivity among common pandora populations. We tested

519 different scenarios in which we assumed a different role of passive and

520 active dispersal in determining the observed population structure in the

521 western Mediterranean Sea. Our model selection approach suggests a

522 scenario in which the gene flow over long distances is due to dispersal of

523 eggs and larvae by oceanic currents, whereas at a small scale can effectively

524 be affected by adult's movement. This scenario agrees with what we know

525 about the biology of this species. Thus, it is likely that gene flow between

526 neighboring sites (on the same coast or connected by a body of water less

527 than $300 \mathrm{~m}$ deep) can occur by active movement of adults, even though a

528 contribution by sea currents to the gene flow among neighboring sites

529 cannot be completely ruled out. We tried to determine the potential

530 contribution of adult and larval migration over short distances by assessing

531 the influence of both oceanic and geographic distances on the estimated

532 mean gene flow in the best-supported migration scenario of Model 3.

533 Therefore, our results suggest that over long distances hydrodynamic

534 connectivity and gene flow in the common pandora are affected by dispersal

535 of eggs and larvae, and thus directly by oceanic circulations, gyres and

536 barriers present within the Mediterranean Sea (Limborg et al., 2012). On the

537 other hand, over short distances, it is likely that a mixed contribution by sea

538 currents, adult movements and/or other biophysical phenomena determines

539 the exchange among populations. As an example, recently simulated

540 scenarios on other sparids showed that larval behavior could actually affect

541 connectivity: swimming abilities of just few $\mathrm{cm} \mathrm{s}^{-1}$, at the end of the pelagic

542 phase, can impact on the rate of recruitment and change connectivity

543 patterns at regional scale (Faillettaz et al., 2018). 
544 All these phenomena act at different scales determining a lack of spatial

545 genetic structure. Further studies are necessary for a generalization of this

546 connectivity pattern to other demersal fishes, but it is important to stress that

547 a similar pattern of genetic structure was reported in the same geographic

548 area for another sparid, the coastal S. aurata (Franchini et al., 2012), which

549 has a comparable long-lasting larval stage (about 50 days).

550 Finally, it is important to frame the excess of homozygotes observed in the

551 sampled populations within the gene flow scenario supported by our 552 analyses. Under a scenario of weak population structure and extensive gene

553 flow (as confirmed by $F_{S T}$ and MIGRATE-N analyses), a high proportion of

554 heterozygoses at most of the sampled loci is expected. On the other side, a 555 recent study on the evolutionary consequences of alternative sex change 556 pathways by Benvenuto et al. (2017) demonstrated a reduction of the 557 effective population in protogynous fishes and also reported a reduction of 558 heterozygotes in $P$. erythrinus. Further data indicate that biophysical 559 phenomena can cause a long-term aggregation of larval fish siblings during 560 dispersal, causing a deviation from Hardy-Weinberg proportions in samples 561 containing a high proportion of related individuals (Ottmann et al., 2016). 562 Thus, in P. erythrinus the extensive gene flow could be compatible with an 563 excess of homozygotes, considering an effective low number of breeders or 564 other phenomena that allow the passive dispersal of large numbers of 565 siblings.

\section{Conclusion}

569 A quantitative method that evaluates the effect of hydrodynamic 
570 connectivity on gene flow can be a powerful tool for an understanding of the

571 population genetics and dynamics of demersal fishes. Our seascape genetic

572 analyses in the common pandora allowed us to elucidate population

573 dynamics and dispersal patterns, confirming the usefulness of genetic

574 approaches in testing predictions about transport mechanisms in the sea

575 (Selkoe et al., 2016). Our results suggest that gene flow across the central

576 Mediterranean Sea in the common pandora, and likely in other demersal

577 fishes, is extremely complex and driven by a combination of factors acting

578 at different scales, including movements of both adults and eggs and larval

579 migration. The complex pattern detected in the central Mediterranean Sea

580 suggests that in fish population genetic studies, hydrodynamic connectivity

581 estimates can help not only to understand the distribution of genetic

582 diversity but also to study dispersal patterns of demersal fishes. Moreover,

583 clarifying the interactions between hydrodynamic connectivity and

584 population genetics could provide useful information for fisheries

585 management and for the better design of marine protected areas (Andrello et

586 al., 2015)

587

588 ACKNOWLEDGEMENTS

589 We thank the MEDITS coordinators and all of our colleagues for their

590 invaluable help with sample collection, specifically Maria Teresa Spedicato

591 and Giuseppe Lembo, COISPA (Bari); Angelo Cau, Dept. of Life and

592 Environmental Sciences, Cagliari University; Corrado Piccinetti, Dept. of

593 Biological, Geological and Environmental Sciences, Bologna University;

594 Angelo Tursi, Dept. of Biology, Bari University; Fabio Fiorentino, Coastal

595 Marine Environment Institute, Mazara del Vallo and Mohamed Salah 
596 Romdhane, INAT/Université de Carthage, Tunisia. Financial support for 597 this work was provided by Sapienza University of Rome, Sapienza Projects 598 2014, grant C26A143AL3 


\section{REFERENCES}

601

602 Aljanabi, S. M. \& I. Martinez,1997. Universal and rapid salt extraction of

603 high quality genomic DNA for PCR-based techniques. Nucleic Acids

604 Research 25:4692-4693.

605 Almany, G. R., M. L. Berumen, S. R. Thorrold, S. Planes \& G. P. Jones, 606 2007. Local replenishment of coral reef fish populations in a marine 607 reserve. Science 316: 742-744.

608 Andrello, M., M. N. Jacobi, S. Manel, W. Thuiller \& D. Mouillot, 2015.

609 Extending networks of protected areas to optimize connectivity and 610 population growth rate. Ecography 38:273-282.

611 Angers, B. \& L. Bernatchez, 1998. Combined use of SMM and non-SMM 612 methods to infer fine structure and evolutionary history of closely related 613 brook charr (Salvelinus fontinalis, Salmonidae) populations from 614 microsatellites. Molecular Biology and Evolution 15:143-159

615 Angiulli, E., L. Sola, G. Ardizzone, C. Fassatoui \& A. R. Rossi, 2016. 616 Phylogeography of the common pandora Pagellus erythrinus in the 617 central Mediterranean Sea: sympatric mitochondrial lineages and genetic 618 homogeneity. Marine Biology Research 12:4-15.

619 Antao, T., A. Lopes, R. J. Lopes, A. Beja-Pereira \& G. Luikart,2008. 620 LOSITAN: a workbench to detect molecular adaptation based on a Fst621 outlier method. BMC Bioinformatics 9:323.

622 Avise, J. C., 2000. Phylogeography. The history and formation of species. 623 Harvard University Press: Cambridge, MA.

624 Bauchot, M. L. \& J. C. Hureau,1986. Sparidae. In: Whitehead PJP, Bauchot 625 ML, Hureau JC, Nielsen J, Tortonese E (eds), Fishes of the north-eastern 
627 Beaumont, M. A. \& R. A. Nichols, 1996. Evaluating loci for use in the 628 genetic analysis of population structure. Proceedings of the Royal 629 Society of London B: Biological Sciences 263:1619-1626.

630 Beerli, P., 2006. Comparison of Bayesian and maximum likelihood 631 inference of population genetic parameters. Bioinformatics 22:341-345.

632 Beerli, P. \& J. Felsenstein, 2001. Maximum likelihood estimation of a 633 migration matrix and effective population sizes in $\mathrm{n}$ subpopulations by 634 using a coalescent approach. Proceeding of the National Academy of 635 Science USA 98:4563-4568.

636 Beerli, P. \& M. Palczewski, 2010. Unified framework to evaluate panmixia 637 and migration direction among multiple sampling locations. Genetics $638 \quad 185: 313-326$

639 Benjamini, Y. \& Y. Hochberg,1995. Controlling the false discovery rate: a 640 practical and powerful approach to multiple testing. Journal of the Royal 641 Statistical Society: Statistical methodology 57: 289-300.

642 Benvenuto, C., I. Coscia, J. Chopelet, M. Sala-Bozano \& S. Mariani, 2017. 643 Ecological and evolutionary consequences of alternative sex change 644 pathways in fish. Scientific Reports| 7: 9084

645 Berline, L., A. M. Rammou, A. Doglioli, A. Molcard\& A. Petrenko, 2014. A 646 Connectivity-Based Eco-Regionalization Method of the Mediterranean $647 \quad$ Sea. PLoSONE 9:e111978.

648 Berry, O., P. England, D. Fairclough, G. Jackson\& J. Greenwood, 2012. 649 Microsatellite DNA analysis and hydrodynamic modelling reveal the 650 extent of larval transport and gene flow between management zones in an 
651 exploited marine fish (Glaucosoma hebraicum). Fisheries Oceanography $652 \quad 21: 243-254$.

653 Bertrand, J., L. Gil de Sola, C. Papaconstantinou, C. Relini \& A. 654 Souplet,2002. The general specifications of the MEDITS surveys. 655 Scientia Marina 66:9-17.

656 Bohonak, A. J., 1999. Dispersal, gene flow, and population structure. The 657 Quarterly Review of Biology 74: 21-45.

658 Busalacchi, B., T. Bottari,D. Giordano, A. Profeta \& P. Rinelli, 2014. 659 Distribution and biological features of the common pandora, Pagellus 660 erythrinus (Linnaeus, 1758), in the southern Tyrrhenian Sea (Central 661 Mediterranean). Marine Research 68:491-501

662 Carlsson, J., 2008. Effects of microsatellite null alleles on assignment 663 testing. Journal of Heredity 99: 616-623.

664 Chapuis, M. P. \& A. Estoup,2007. Microsatellite null alleles and estimation 665 of population differentiation. Molecular Biology and Evolution 24:621$666 \quad 631$.

667 Chopelet, J., S. Helyar, B. Mann, \& S. Mariani, 2009. Novel polymorphic 668 microsatellite loci for the ptotogynous hermaphrodite slinger sea bream 669 (Chrysoblephus puniceus, Sparidae). Molecular Ecology Research $670 \quad 9: 1223-1226$.

671 Lorenzo Ciannelli, L., H. Knutsen, E. M. Olsen, S. H. Espeland, L. Asplin, 672 A. Jelmert, J. A. Knutsen and N. C. Stenseth, 2010. Small-scale genetic 673 structure in a marine population in relation to water circulation and egg 674 characteristics. Ecology 91: 2918-2930.

675 Cowen, R. \& S. Sponaugle, 2009. Larval dispersal and marine population 676 connectivity. Annual Review of Marine Science 1:443-466. 
677 Crandall, E. D., E. A. Treml \& P. H. Barber, 2012. Coalescent and 678 biophysical models of stepping-stone gene flow in neritid snails. 679 Molecular Ecology 21: 5579-5598

680 Davies, S. W., E. A. Treml, C. D. Kenkel \& M. V. Matz, 2015. Exploring the 681 role of Micronesian islands in the maintenance of coral genetic diversity 682 in the Pacific Ocean. Molecular Ecology 24: 70-82.

683 Dempster, A. P., N. M. Laird, \& D. B. Rubin,1977. Maximum likelihood 684 from incomplete data via the EM algorithm. Journal of the Royal 685 Statistical Society: Statistical methodology 39:1-38.

686 Dharmarajan, G., W. S. Beatty \& E. R. Olin Jr, 2013. Heterozygote 687 deficiencies caused by a Wahlund effect: Dispelling unfounded 688 expectations. The Journal of Wildlife Management 77: 226-234.

689 Durand, J. D., H. Blel, K. N. Shen, E. T. Koutrakis \&B. Guinand, 2013. 690 Population genetic structure of Mugil cephalus in the Mediterranean and 691 Black Seas: a single mitochondrial clade and many nuclear barriers. 692 Marine Ecology Progress Series 474:243-261.

693 Excoffier, L. \& H. E. L Lischer,2010. Arlequin suite ver 3.5: a new series of 694 programs to perform population genetics analyses under Linux and 695 Windows. Molecular Ecology Resources 10:564-567.

696 Excoffier, L., T. Hofer \& M. Foll,2009. Detecting loci under selection in a 697 hierarchically structured population. Heredity 103:285-298.

698 Faillettaz, R., C. B. Paris \& J. O. Irisson, 2018. Larval fish swimming 699 behavior alters dispersal patterns from marine protected areas in the 700 north-western Mediterranean Sea. Frontiers in Marine Science 5:97.

701 Falush, D., M. Stephens \& J. K. Pritchard, 2003. Inference of population 702 structure using multilocus genotype data: linked loci and correlated allele 
704 FAO, 2018. FishStat plus. Capture production 1950-2012, Aquaculture 705 production 1950-2016.

Available

from

706 http://www.fao.org/fishery/statistics/software/fishstatj/en

Accessed

$707 \quad$ March 2018.

708 Fassatoui, C., E. Mdelgi \& M. S. Romdhane, 2009. A preliminary 709 investigation of allozyme genetic variation and population structure in 710 common pandora (Pagellus erythrinus, Sparidae) from Tunisian and 711 Libyan coasts. Ichthyological Research 56:301-307.

712 Fassatoui, C., E. Mdelgi\& M. S. Romdhane, 2011. Short-term temporal 713 genetic investigation of two populations of Pagellus erythrinus 714 (Linnaeus, 1758, Sparidae) from Western and Eastern Mediterranean 715 basins off the Tunisian coast. Marine Biology Research 7:147-158.

716 Faurby, S. P. H. Barber,2012. Theoretical limits to the correlation between 717 pelagic larval duration and population genetic structure. Molecular $718 \quad$ Ecology 21: 3419-3432.

719 Félix-Hackradt, F. C., C. W. Hackradt, Á. Pérez-Ruzafa \& J. A. García720 Charton, 2013. Discordant patterns of genetic connectivity between two 721 sympatric species, Mullus barbatus (Linnaeus, 1758) and Mullus 722 surmuletus (Linnaeus, 1758), in south-western Mediterranean Sea. 723 Marine Environmental Research 92:23-34.

724 Franchini, P., L. Sola, D. Crosetti, V. Milana\& A. R. Rossi, 2012. Low 725 levels of population genetic structure in the gilthead seabream, Sparus 726 aurata, along the Italian coasts. ICES Journal of Marine Science 69:41$727 \quad 50$.

728 Galarza, J. A., J. Carreras-Carbonell, E. Macpherson, M. Pascual, S. 
729 Roques, G. F. Turner \& C. Rico,2009. The influence of oceanographic

730 fronts and early-life-history traits on connectivity among littoral fish

731 species. Proceedings of the National Academy of Science USA $732 \quad 106: 1473-1478.6$

733 Goodman, S. J., 1997. RSTCALC: A collection of computer programs for

734 calculating unbiased estimates of genetic differentiation and determining

735 their significance for microsatellite data. Molecular Ecology 6:881-885.

736 Goudet, J., 2001. FSTAT, a program to estimate and test gene diversities and

737 fixation indices (version 2.9.3). Institute of Ecology, University of

$738 \quad$ Lausanne, Lausanne, Switzerland

739 Hauser, L, \& J. R. Carvalho, 2008. Paradigm shifts in marine fisheries

740 genetics: ugly hypotheses slain by beautiful facts. Fish and Fisheries $7419: 333-362$.

742 Hedgecock, D. \& A. Pudovkin, 2011. Sweepstakes reproductive success in

743 highly fecund marine fish and shellfish: a review and commentary.

$744 \quad$ Bulletin of Marine Science. 87: 971-1002.

745 Hewitt, G. M., 2004. The structure of biodiversity - insights from molecular 746 phylogeography. Frontiers in Zoology 1:4.

747 Horne, J. B., L. van Herwerden, S. Abellana \& J. L. McIlwain, 2013.

748 Observations of migrant exchange and mixing in a coral reef fish

749 metapopulation link scales of marine population connectivity. Journal of $750 \quad$ Heredity 104: 532-546.

751 I.I.M. Istituto Idrografico della Marina 1982 Atlante delle correnti 752 superficiali dei mari italiani 3068.

753 Jombart, T., 2008. Adegenet: a R package for the multivariate analysis of 754 genetic markers. Bioinformatics 24:1403-1405. 
755 Jombart, T. \& I. Ahmed, 2011. Adegenet 1.3-1: new tools for the analysis of 756 genome-wide SNP data. Bioinformatics 27:3070-1.

757 Jombart, T., S. Devillard \& F. Balloux, 2010. Discriminant analysis of 758 principal components: a new method for the analysis of genetically 759 structured populations. BMC Genetics 11:94.

760 Jones, G. P., G. R. Almany, G. R. Russ, P. F. Sale, R. S. Steneck, M. J. H. van

761 Oppen \& B. L. Williset, 2009. Larval retention and connectivity among 762 populations of corals and reef fishes: history, advances and challenges. 763 Coral Reefs 28: 307-325.

764 Kelly, R. P. \& S. R. Palumbi, 2010. Genetic structure among 50 species of 765 the northeastern Pacific rocky intertidal community. PLoS One. 2010 Jan $766 \quad 7 ; 5: \mathrm{e} 8594$.

767 Klaoudatos, S. D., G. Iakovopoulos \& D. S. Klaoudatos, 2004. Pagellus 768 erythrinus (common pandora): a promising candidate species for 769 enlarging the diversity of aquaculture production. Aquaculture $770 \quad$ International 12:299-320.

771 Klimogianni, A., G. Koumoundouros, P. Kaspiris \& M. Kentouri, 2004. 772 Effect of temperature on the egg and yolk-sac larval development of 773 common pandora, Pagellus erythrinus. Marine Biology 145: 1015-1022.

774 Knutsen, H., P. E. Jorde, C. Andre\& N. C. Stenseth, 2003. Fine-scaled 775 geographic population structuring in a highly mobile marine species: the 776 Atlantic cod. Molecular Ecology 12:385-39.

777 Latch, E. K., G. Dharmarajan, J. C. Glaubitz\& O. E. Rhodes, 2006. Relative 778 performance of Bayesian clustering software for inferring population 779 substructure and individual assignment at low levels of population 780 differentiation. Conservation Genetics 7:295-302. 
781 Lemos, A., A. I. Freitas, A. T. Fernandes, R. Goncalves, J. Jesus \& C.

782 Andrade, 2006. Microsatellite variability in natural populations of the

783 blackspot seabream Pagellus bogaraveo (Brünnich, 1768): a database to

784 access parentage assignment in aquaculture. Aquaculture Research $785 \quad 37: 1028-1033$.

786 Liggins, L., E. A. Trem, H.P. Possingham \& C. Riginos, 2016. Seascape

787 features, rather than dispersal traits, predict spatial genetic patterns in co-

788 distributed reef fishes. Journal of Biogeography 43: 256-267.

789 Limborg, M. T., R. Hanel, P. V. Debes, A. K. Ring, C. André, C. S.

790 Tsigenopoulos \& D. Bekkevold, 2012. Imprints from genetic drift and

791 mutation imply relative divergence times across marine transition zones

792 in a pan-European small pelagic fish (Sprattus sprattus). Heredity $793 \quad 109: 96-107$.

794 Macpherson, E. \& N. Raventos, 2006. Relationship between pelagic larval 795 duration and geographic distribution of Mediterranean littoral fishes. 796 Marine Ecology Progress Series 327:257-265.

797 MEDITS Biological Report 2001 available at 798 http://www.sibm.it/SITO\%20MEDITS/principaleprogramme.htm).

799 Millot, C. \& I. Taupier-Letage, 2005. Circulation in the Mediterranean Sea.

800 In: Saliot A (ed.) The Mediterranean Sea Vol 5k of Handbook of 801 Environmental Chemistry. Springer: Berlin. p 29-66.

802 Mitarai, S., D. A. Siegel, J. R. Watson, C. Dong, C. \& J. C. McWilliams, 803 2009. Quantifying connectivity in the coastal ocean with application to 804 the Southern California Bight. Journal of Geophysical Research 114: $805 \quad$ C10026.

806 Modica, M.V., V. Russini, G. Fassio \& M. Oliverio, 2017. Do larval types 
807 affect genetic connectivity at sea? Testing hypothesis in two sibling

808 marine gastropods with contrasting larval development. Marine

$809 \quad$ Environmental Research 127 92e101

810 Nanninga, G. B. \& A. Manica, 2018. Larval swimming capacities affect

811 genetic differentiation and range size in demersal marine fishes. Marine

812 Ecology Progress Series 589: 1-12.

813 Ovenden, J. R., J. Salini, S. O’Connor \& R. Street, 2004. Pronounced 814 genetic population structure in a potentially vagile fish species 815 (Pristipomoides multidens, Teleostei;Perciformes; Lutjanidae) from the 816 East Indies triangle. Molecular Ecology 13: 1991-1999.

817 Palero, F., P. Abello, E. Macpherson, M. Gristina \& M. Pascual, 2008. 818 Phylogeography of the European spiny lobster (Palinurus elephas): 819 influence of current oceanographical features and historical processes. 820 Molecular Phylogenetics and Evolution 48:708-717.

821 Pascual, M., B. Rives, C. Schunter \& E. Macpherson,2017. Impact of life 822 history traits on gene flow: A multispecies systematic review across 823 oceanographic barriers in the Mediterranean Sea. PLoSONE $824 \quad 12: \mathrm{e} 0176419$.

825 Piñera, J. A., D. Bernardo, G. Blanco, E. Vazquez \&J. A. Sanchez, 2006.

826 Isolation and characterization of polymorphic microsatellite markers in 827 Pagellus bogaraveo, and cross-species amplification in Sparus aurata 828 and Dicentrarchus labrax. Molecular Ecology Notes 6:33-35.

829 Pinet, P. R., 2009. Invitation to Oceanography, 5th edn. Jones and Bartlett 830 Publishers, Burlington, MA, USA.

831 Piry, S., G. Luikart \& J. M. Cornuet,1999. BOTTLENECK: a computer 832 program for detecting recent reductions in the effective population size 

using allele frequency data. Journal of Heredity 90:502-503.

834 Pritchard, J. K., M. Stephens, P. Donnelly,2000. Inference of population 835 structure using multilocus genotype data. Genetics 155:945-959.

836 Ramsak, A., F. Garoia, I. Guarniero, P. Mannini\& F. Tinti,2003. Novel

837 polymorphic microsatellite markers for the common pandora (Pagellus

838 erythrinus). Molecular Ecology Notes 3:553-555.

839 Raymond, M. \& F. Rousset,1995. An exact test for population 840 differentiation. Evolution 49:1280-1283.

841 R Development Core Team, 2011. R: A language and environment for 842 statistical computing. R Foundation for Statistical Computing, Vienna, 843 Austria ISBN 3-900051-07-0, URL http://www.R-project.org

844 Riginos, C., K. E. Douglas, Y. Jin, D. F. Shanahan, \& E. A. Treml, 2011. 845 Effects of geography and life history traits on genetic differentiation in 846 benthic marine fishes. Ecography 34: 566-575.

847 Riginos, C. \& L. Liggins, 2013. Seascape genetics: populations, individuals, 848 and genes marooned and adrift. Geography Compass 7: 197-216.

849 Robitzch, V. S. N., D. Lozano-Cortés, N. M. Kandler, E. Salas \& M. L. 850 Berumen, 2016. Productivity and sea surface temperature are correlated 851 with the pelagic larval duration of damselfishes in the Red Sea. Marine $852 \quad$ Pollution Bulletin 105: 566-574.

853 Ryman, N. \& S. Palm, 2006. POWSIM: a computer program for assessing 854 statistical power when testing for genetic differentiation. Molecular 855 Ecology Notes 6:600-602.

856 Sabatés, A. \& M. P. Olivar, 1996. Variation of larval fish distributions 857 associated with variability in the location of a shelf-slope front. Marine $858 \quad$ Ecology Progress Series 135: 11-20. 
859 Sala-Bozano, M., V. Ketmaier \& S. Mariani, 2009. Contrasting signals from

860 multiple markers illuminate population connectivity in a marine fish.

$861 \quad$ Molecular Ecology 18:4811-4826.

862 Schunter, C., J. Carreras-Carbonell, E. Macpherson, J. Tintore, E. Vidal-

863 Vijande, \& A. Guidetti \&M. Pascual, 2011. Matching genetics with

864 oceanography: directional gene flow in a Mediterranean fish species.

865 Molecular Ecology 20:5167-5181.

866 Selkoe, K. A., K. T. Scribner\& H. M. Galindo, 2016. Waterscape Genetics -

867 Applications of landscape genetics to rivers, lakes, and seas. In:

868 Balkenhol N, Cushman SA, Storfer AT, Waits LP (eds) Landscape

869 Genetics - concepts, methods, applications, Wiley \& Sons, Chichester,

$870 \quad$ UK. p 220-246.

871 Silva, G., J. B. Horne\& R. Castilho,2014. Anchovies go north and west

872 without losing diversity: post-glacial range expansions in a small pelagic

873 fish. Journal of Biogeography 41:1171-1182.

874 Simpson, S.D., H. B. Harrison, M. R. Claereboudt \&S. Planes, 2014. Long-

875 Distance dispersal via ocean currents connects Omani clownfish

876 populations throughout entire species range. PLoSONE 9:e107610.

877 Slatkin, M., 1995. A measure of population subdivision based on

878 microsatellite allele frequencies. Genetics 139: 457-462

879 Swearer, S. E., J. E. Caselle, D. W. Lea \& R. R. Warner, 1999. Larval

880 retention and recruitment in an island population of a coral-reef fish.

$881 \quad$ Nature 402: 799-802.

882 Weersing, K. \& R. J. Toonen, 2009. Population genetics, larval dispersal,

883 and connectivity in marine systems. Marine Ecology Progress Series 393:

$884 \quad 1-12$. 
885 Weir, B. S. \& C. C. Cockerham, 1984. Estimating F-statistics for the 886 analysis of population structure. Evolution, 38: 1358-1370

887 White, C., K. A. Selkoe, J. Watson, D. A. Siegel, D. C. Zacher \& R. J. 888 Toonen, 2010. Ocean currents help explain population genetic structure. 889 Proceedings of the Royal Society B 277: 1685-1694.

890 Valdés, P., A. García-Alcázar, I. Abdel, M. Arizcun, C. Suárez \& E. Abellán, 891 2004. Seasonal changes on gonadosomatic index and maturation stages 892 in common pandora Pagellus erythrinus (L.). Aquaculture International $89312: 333-343$.

894 Van Etten J., 2017. R Package gdistance: Distances and Routes on 895 Geographical Grids. Journal of Statistical Software 76: 1-21.

896 Van Oosterhout, C., W. F. Hutchinson, D. P. M. Wills \& P. Shipley, 2004. 897 Micro- checker: software for identifying and correcting genotyping 898 errors in microsatellite data. Molecular Ecology Notes 4: 535-538.

899 Villamor, A., F. Costantini \& M. Abbiati, 2014. Genetic Structuring across 900 marine biogeographic boundaries in rocky shore invertebrates. $901 \quad$ PLoSONE, 9, e101135.

902 Županović, Š. \& I. Jardas, 1989. Fauna i flora Jadrana. Logos Split. 526 pp. 903 904 
905 FIGURE LEGENDS

906

907 Fig. 1 Fig. 1 Map of the sampling sites of P. erythrinus, abbreviated as in

908 Table1. Grey outline indicates the $300 \mathrm{~m}$ isobath within which P. erythrinus

909 adults can actively move and above which they cannot be found.

910

911 Fig. 2 Different models of population connectivity. Model 0: sampled

912 populations belong to a unique panmictic unit; Model 1-7: populations are

913 pooled according to different criteria or are considered as independent units,

914 and different option of migration are allowed (see text for details).

915

916 Fig. 3 Frequency distribution of the four clusters identified by discriminant

917 analysis of principal components across sampling sites.

918

919 Fig. 4 Migration rates between localities according to Model 3. (a) The

920 median estimate is reported (vertical dash) with 50\% (bold continuous line)

921 and $95 \%$ (dotted line) confidence intervals; (b) Thickness of the arrows is 922 proportional to the mean estimate. 


\section{ELECTRONIC SUPPLEMENTARY MATERIAL}

924

925 Online resource 1 Summary statistics for 10 microsatellite loci over the 12

926 common pandora sampling sites analyzed.

927

928 Online resource 2 Locus/site combination tests for null alleles (NA; in 929 parentheses their estimated frequencies) and for stuttering errors (ST). In 930 grey, deviations from Hardy-Weinberg expectations.

931

932 Online resource 3 POWSIM simulations

933

934 Online resource 4 Discriminant Analysis of Principal Component (DAPC).

935

936 Online resource 5 Calculated mean connection time (MCT) between pairs

937 of sites

938

939 Online resource 6 Comparison of the eight models. For each model, the

940 marginal likelihood estimated using the Bezier approximation is reported. 
941 Table 1 Details for sampling and summary statistics over ten loci. N: number of individuals, 942 A: average number of alleles, $\mathrm{N}_{\mathrm{P}}$ : number of private alleles, $\mathrm{H}_{\text {exp }}$ : mean expected 943 heterozygosity, $\mathrm{H}_{\mathrm{obs}}$ : mean observed heterozygosity, Fis: inbreeding coefficient (all the 944 values are significant for $\mathrm{p}<0.0001$ ).

\begin{tabular}{|c|c|c|c|c|c|c|c|c|c|c|}
\hline Sea & Locality name & $\begin{array}{l}\text { Geographic } \\
\text { coordinates }\end{array}$ & $\begin{array}{l}\text { Locality } \\
\text { code }^{1}\end{array}$ & $\begin{array}{c}\text { Collection } \\
\text { year }\end{array}$ & $\mathbf{N}$ & A & $\mathbf{N P}_{\mathbf{P}}$ & $H_{\text {exp }}$ & Hobs & Fis \\
\hline \multirow[t]{2}{*}{ Adriatic Sea } & Ancona & $\begin{array}{l}44^{\circ} 12^{\prime} \mathrm{N} \\
13^{\circ} 15^{\prime} \mathrm{E} \\
41^{\circ} 25^{\prime} \mathrm{N}\end{array}$ & $\mathrm{AN}^{\mathrm{M}}$ & 2010 & 38 & 24 & 9 & 0.885 & 0.7746 & 0.138 \\
\hline & Bari & $\begin{array}{l}16^{\circ} 10^{\prime} \mathrm{E} \\
38^{\circ} 20^{\prime} \mathrm{N}\end{array}$ & $\mathrm{BA}^{\mathrm{M}}$ & 2010 & 42 & 23.8 & 8 & 0.8614 & 0.7483 & 0.143 \\
\hline Ionian Sea & Acitrezza & $\begin{array}{l}16^{\circ} 90^{\prime} \mathrm{E} \\
42^{\circ} 59^{\prime} \mathrm{N}\end{array}$ & $\mathrm{JO}^{\mathrm{M}}$ & 2010 & 39 & 25.4 & 7 & 0.8706 & 0.7576 & 0.143 \\
\hline $\begin{array}{l}\text { Ligurian Sea } \\
\text { East }\end{array}$ & Elba & $\begin{array}{l}10^{\circ} 22^{\prime} \mathrm{E} \\
41^{\circ} 41^{\prime} \mathrm{N}\end{array}$ & $\mathrm{EN}^{\mathrm{M}}$ & 2010 & 40 & 23.8 & 3 & 0.8953 & 0.7763 & 0.146 \\
\hline \multirow[t]{3}{*}{ Tyrrhenian Sea } & Fiumicino & $\begin{array}{l}12^{\circ} 40^{\prime} \mathrm{E} \\
41^{\circ} 11^{\prime} \mathrm{N}\end{array}$ & $\mathrm{FM}^{\mathrm{C}}$ & 2010 & 40 & 24.6 & 4 & 0.8721 & 0.7838 & 0.114 \\
\hline & Gaeta & $\begin{array}{l}13^{\circ} 26^{\prime} \mathrm{E} \\
38^{\circ} 45^{\prime} \mathrm{N}\end{array}$ & $\mathrm{GA}^{\mathrm{M}}$ & 2010 & 32 & 22 & 6 & 0.867 & 0.7572 & 0.143 \\
\hline & Vibo Marina & $\begin{array}{l}16^{\circ} 80^{\prime} \mathrm{E} \\
40^{\circ} 84^{\prime} \mathrm{N}\end{array}$ & $\mathrm{VM}^{\mathrm{C}}$ & 2010 & 40 & 22.9 & 6 & 0.8644 & 0.7382 & 0.158 \\
\hline Sardinian Sea & Castel Sardo & $\begin{array}{l}08^{\circ} 34^{\prime} \mathrm{E} \\
40^{\circ} 32^{\prime} \mathrm{N}\end{array}$ & $\mathrm{SN}^{\mathrm{M}}$ & 2010 & 40 & 24.4 & 6 & 0.8825 & 0.7517 & 0.161 \\
\hline Sicilian & Alghero & $\begin{array}{l}08^{\circ} 11^{\prime} \mathrm{E} \\
37^{\circ} 16^{\prime} \mathrm{N}\end{array}$ & $\mathrm{AL}^{\mathrm{M}}$ & 2010 & 39 & 23.7 & 6 & 0.8793 & 0.7622 & 0.146 \\
\hline \multirow[t]{3}{*}{ Channel } & Bizerte (Tunisia) & $\begin{array}{l}09^{\circ} 55^{\prime} \mathrm{E} \\
35^{\circ} 11^{\prime} \mathrm{N}\end{array}$ & $\mathrm{BZ}^{\mathrm{C}}$ & 2009 & 40 & 24.2 & 3 & 0.8654 & 0.7678 & 0125 \\
\hline & Lampedusa & $\begin{array}{l}12^{\circ} 70^{\prime} \mathrm{E} \\
33^{\circ} 24^{\prime} \mathrm{N}\end{array}$ & $\mathrm{LM}^{\mathrm{C}}$ & 2010 & 40 & 23.6 & 1 & 0.8745 & 0.7691 & 0.133 \\
\hline & Zarzis (Tunisia) & $11^{\circ} 13^{\prime} \mathrm{E}$ & $\mathrm{ZA}^{\mathrm{C}}$ & 2009 & 40 & 24.1 & 6 & 0.8824 & 0.8025 & 0.103 \\
\hline
\end{tabular}

$946{ }^{1}$ Superscript character indicate sampling source: M, MEDITS survey; C, commercial fishing 
947 Table $2 F_{S T}$ values (Weir \& Cockerham 1984, below the diagonal) and $R_{S T}$ (Slatkin, 1995; 948 above the diagonal) calculated for each pair of sampling locations. Significant values before 949 and after FDR correction are indicated underlined and bold respectively. For sample codes see 950 Table 1

\begin{tabular}{ccccccccccccc}
\hline & AN & BA & JO & EN & FM & GA & VM & SN & AL & BZ & LM & ZA \\
\hline AN & - & $\underline{0.0194}$ & 0.0016 & 0.0025 & 0.0014 & 0.0031 & 0.0067 & 0.002 & 0.0038 & -0.0083 & $\underline{0.0196}$ & 0.0097 \\
BA & $\underline{\mathbf{0 . 0 0 9 2}}$ & - & 0.0066 & $\underline{0.0169}$ & 0.0091 & $\underline{\mathbf{0 . 0 3 7 7}}$ & 0.0115 & 0.0049 & 0.0112 & 0.007 & 0.0079 & 0.0097 \\
JO & $\underline{0.0073}$ & $\underline{0.0055}$ & - & 0.0054 & -0.0001 & 0.0119 & 0.0001 & -0.0016 & -0.0077 & -0.0051 & 0.0067 & 0.0055 \\
EN & $\underline{0.0065}$ & $\underline{0.0064}$ & $\underline{0.0061}$ & - & -0.0078 & 0.0052 & 0.0017 & -902 & 0.0135 & 0.0024 & $\underline{0.0138}$ & $\underline{0.0125}$ \\
FM & $\underline{0.0055}$ & 0.0041 & 0.0025 & 0.0024 & - & 0.0014 & -0.0056 & -0.008 & 0.0043 & -0.0006 & 0.0108 & $\underline{0.0131}$ \\
GA & 0.0024 & 0.0032 & 0.0023 & 0.0041 & 0.0005 & - & 0.0072 & 0.0063 & 0.015 & 0.003 & $\underline{0.0294}$ & $\underline{0.0332}$ \\
VM & $\underline{0.0075}$ & 0.0013 & 0.0046 & $\underline{0.0058}$ & 0.0008 & 0.0018 & - & -0.0007 & 0.0012 & 0.0051 & $\underline{0.013}$ & 0.0048 \\
SN & $\underline{0.0063}$ & 0.004 & $\underline{0.0051}$ & 0.0003 & 0.0033 & 0.0042 & 0.0051 & - & 0.0055 & -195 & 0.0103 & 0.0098 \\
AL & 0.0039 & 0.0011 & -0.0009 & 0.0044 & 0.0002 & -0.0016 & 0.0003 & $\underline{0.0059}$ & - & -0.0025 & 0.0135 & 0.0004 \\
BZ & 0.004 & $\underline{0.0051}$ & 0.003 & $\underline{0.0072}$ & 0.0029 & 0.0017 & 0.0037 & $\underline{0.0063}$ & 0.0005 & - & 0.0027 & 0.0036 \\
LM & $\underline{0.0065}$ & 0.0027 & 0.004 & $\underline{0.0049}$ & 0.0017 & 0.0016 & 0.0039 & 0.0041 & 0.0022 & 0.0039 & - & 0.0082 \\
ZA & $\underline{0.0078}$ & 0.0042 & 0.0022 & $\underline{0.0067}$ & 0.0037 & $\underline{0.0057}$ & $\underline{0.006}$ & $\underline{0.0058}$ & 0.0002 & $\underline{0.0065}$ & $\underline{0.0058}$ & - \\
\hline
\end{tabular}




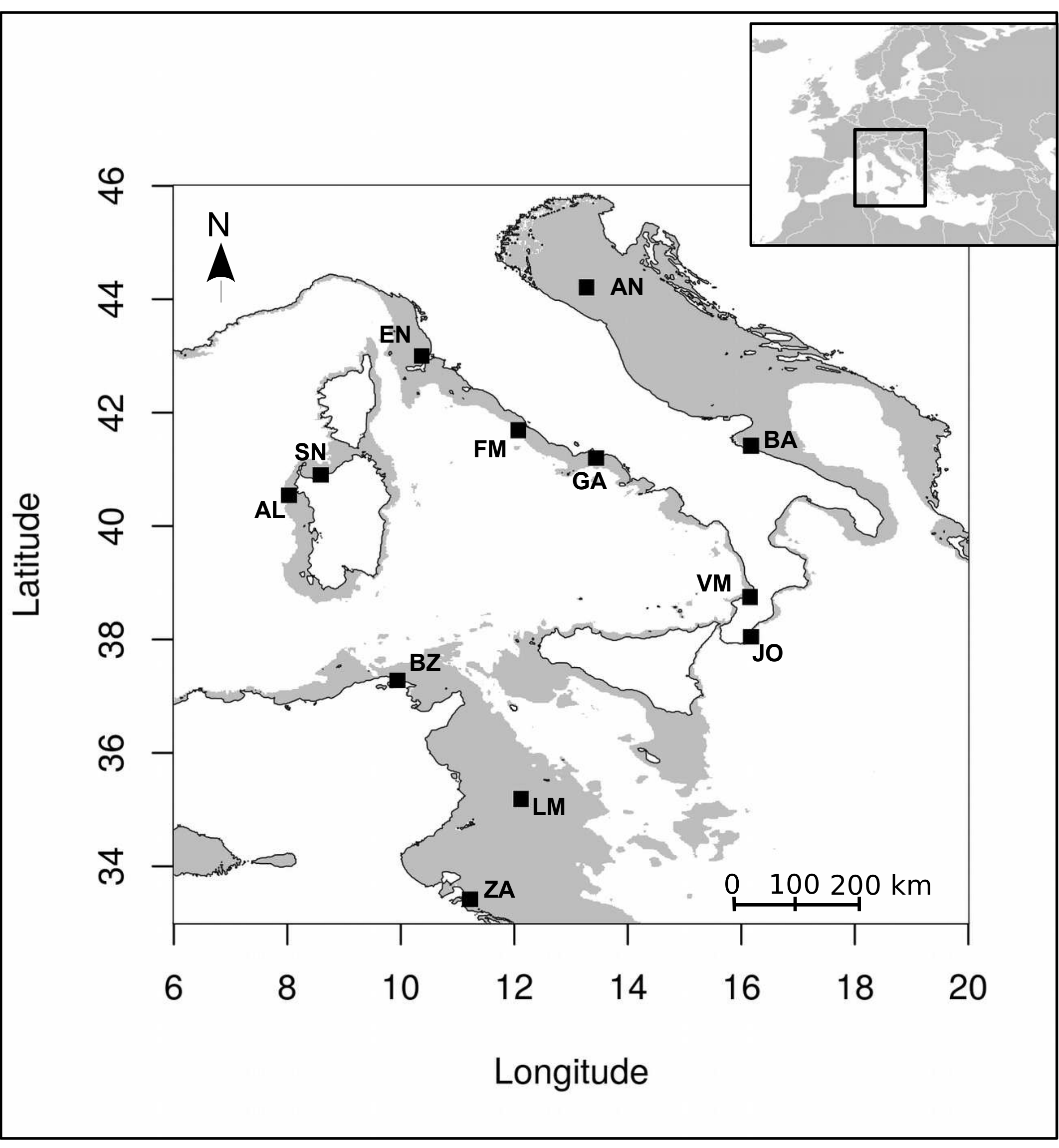




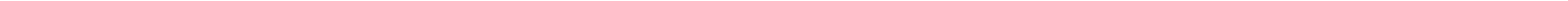




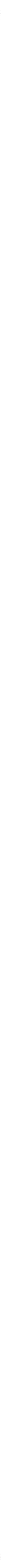




\section{Electronic Supplementary Material}

\section{Influence of hydrodynamic connectivity on the genetic structure and gene flow of the common pandora Pagellus erythrinus}

Anna Rita Rossi, Paolo Colangelo, Léo Berline, Elisa Angiulli, Giandomenico Ardizzone, Chiheb Fassatoui, Luciana Sola

Online resource 1. Summary statistics for ten microsatellite loci over the twelve common pandora sampling sites analysed

\begin{tabular}{|l|l|l|l|l|l|l|l|l|}
\hline Locus & $\mathrm{N}$ & $\mathrm{K}$ & $\mathrm{Np}$ & $\mathrm{A}$ & $\mathrm{A}_{\mathrm{R}}$ & $\mathrm{H}_{\mathrm{WE}}$ & Fis & Null All \\
\hline MS2 & 467 & 83 & 11 & 35.6 & 33.16 & High sign & 0.272 & 0.131 \\
\hline MS3 & 465 & 43 & 13 & 15.7 & 14.25 & High sign & 0.183 & 0.075 \\
\hline MS4 & 465 & 42 & 6 & 25.4 & 23.46 & High sign & 0.092 & 0.043 \\
\hline MS6 & 468 & 14 & 3 & 6.4 & 6.11 & 0.0000 & 0.089 & 0.047 \\
\hline SL7 & 464 & 55 & 5 & 34.9 & 31.58 & High sign & 0.130 & 0.063 \\
\hline SL17 & 469 & 77 & 6 & 33 & 28.75 & High sign & 0.099 & 0.050 \\
\hline SL26 & 465 & 34 & 7 & 17.8 & 17.58 & High sign & 0.081 & 0.035 \\
\hline SL29 & 464 & 61 & 4 & 37.1 & 33.69 & High sign & 0.071 & 0.033 \\
\hline SL33 & 466 & 17 & 6 & 8.3 & 7.89 & High sign & 0.354 & 0.160 \\
\hline PbOviD102 & 466 & 38 & 4 & 22.6 & 22.60 & 0.0280 & 0.032 & 0.016 \\
\hline & & & & & & & & \\
\hline & & & & & & & & \\
\hline
\end{tabular}

$\mathrm{N}=$ number of individuals, $\mathrm{K}=$ allele number, $\mathrm{NP}=$ number of private alleles, $\mathrm{A}=$ average number of allelels, AR = Allelic richness, $\mathrm{HWE}=$ significance deviation from the Hardy-Weinberg equilibrium, Fis = inbreeding coefficient; Null All = null alleles frequencies 


\section{Electronic Supplementary Material}

\section{Influence of hydrodynamic connectivity on the genetic structure and gene flow of the common pandora Pagellus erythrinus}

Anna Rita Rossi, Paolo Colangelo, Léo Berline, Elisa Angiulli, Giandomenico Ardizzone, Chiheb Fassatoui, Luciana Sola

Online resource 2. Locus/site combination tests for null alleles (NA; in parentheses their estimated frequencies) and for stuttering errors (ST). In grey deviations from Hardy-Weinberg expectations

\begin{tabular}{|c|c|c|c|c|c|c|c|c|c|c|c|c|}
\hline \multirow[t]{2}{*}{ Locus } & \multicolumn{12}{|c|}{ Locality } \\
\hline & $\mathrm{AN}$ & $\mathrm{BA}$ & $\mathrm{JO}$ & EN & $\mathrm{FM}$ & GA & $\mathrm{VM}$ & $\mathrm{SN}$ & $\mathrm{AL}$ & $\mathrm{BZ}$ & LM & $\mathrm{ZA}$ \\
\hline MS2 & $\begin{array}{c}\text { NA } \\
(0.18605)\end{array}$ & $\begin{array}{c}\text { NA } \\
(0.08541)\end{array}$ & $\begin{array}{c}\text { NA } \\
(0.09873)\end{array}$ & $\begin{array}{c}\text { NA } \\
(0.11984)\end{array}$ & $\begin{array}{c}\text { NA } \\
(0.09713)\end{array}$ & $\begin{array}{c}\text { NA } \\
(0.12473)\end{array}$ & $\begin{array}{c}\text { NA } \\
(0.15418)\end{array}$ & $\begin{array}{c}\text { NA } \\
(0.04502)\end{array}$ & $\begin{array}{c}\text { NA } \\
(0.12457)\end{array}$ & $\begin{array}{c}\text { NA } \\
(0.13913)\end{array}$ & $\begin{array}{c}\text { NA } \\
(0.16967)\end{array}$ & $\begin{array}{c}\text { NA } \\
(0.13864)\end{array}$ \\
\hline MS3 & $(0.01970)$ & $(0.03759)$ & $(0.05090)$ & $(0.06050)$ & $\begin{array}{c}\text { NA } \\
(0.12828)\end{array}$ & $\begin{array}{c}\text { NA/ST } \\
(0.13478)\end{array}$ & $(0.07617)$ & $\begin{array}{c}\text { NA/ST } \\
(0.09982)\end{array}$ & $(0.07332)$ & $(0.01328)$ & $(0.09435)$ & $(0.02852)$ \\
\hline MS4 & $(0.06117)$ & $(0.05013)$ & $(0.01877)$ & $(0.02947)$ & $(0.05440)$ & $(0.01664)$ & $\begin{array}{c}\text { NA } \\
(0.07836)\end{array}$ & $(0.01451)$ & $\begin{array}{c}\text { NA } \\
(0.06293)\end{array}$ & $(0.00000)$ & $(0.00630)$ & $(0.04910)$ \\
\hline MS6 & $(0.00000)$ & $(0.08305)$ & $(0.00570)$ & $(0.14292)$ & $(0.00402)$ & $(0.00000)$ & $(0.13088)$ & $(0.00465)$ & $(0.09737)$ & $(0.00000)$ & $(0.00000)$ & $(0.01637)$ \\
\hline SL7 & $(0.03341)$ & $\begin{array}{c}\text { NA } \\
(0.08705)\end{array}$ & $\begin{array}{c}\text { NA } \\
(0.07270)\end{array}$ & $(0.04892)$ & $(0.06008)$ & $\begin{array}{c}\text { NA } \\
(0.08435)\end{array}$ & $(0.03329)$ & $\begin{array}{c}\text { NA } \\
(0.11093)\end{array}$ & $(0.03009)$ & $\begin{array}{c}\text { NA } \\
(0.06539)\end{array}$ & $(0.04558)$ & $(0.01979)$ \\
\hline SL17 & $(0.02042)$ & $(0.08967)$ & $(0.10918)$ & $(0.00063)$ & $(0.00476)$ & $(0.00334)$ & $(0.06868)$ & $(0.03620)$ & $(0.06292)$ & $(0.07935)$ & $(0.06352)$ & $(0.00000)$ \\
\hline SL26 & $(0.04173)$ & $(0.03611)$ & $(0.03955)$ & $\begin{array}{c}\text { NA } \\
(0.08419)\end{array}$ & $(0.00000)$ & $(0.04894)$ & $(0.00000)$ & $(0.05848)$ & $\begin{array}{c}\text { NA } \\
(0.07646)\end{array}$ & $(0.04591)$ & $(0.00000)$ & $(0.00000)$ \\
\hline SL29 & $(0.02698)$ & $(0.00000)$ & $\begin{array}{c}\text { NA } \\
(0.06144)\end{array}$ & $(0.01355)$ & $(0.00000)$ & $(0.02539)$ & $(0.00000)$ & $(0.01637)$ & $(0.04653)$ & $\begin{array}{c}\text { NA } \\
(0.04492)\end{array}$ & $(0.03507)$ & $(0.05382)$ \\
\hline SL33 & $\begin{array}{c}\mathrm{NA} / \mathrm{ST} \\
(0.20935) \\
\end{array}$ & $\begin{array}{c}\text { NA/ST } \\
(0.12897) \\
\end{array}$ & $\begin{array}{c}\text { NA/ST } \\
(0.16804) \\
\end{array}$ & $\begin{array}{c}\text { NA/ST } \\
(0.08890) \\
\end{array}$ & $\begin{array}{c}\text { NA/ST } \\
(0.10385 \\
\end{array}$ & $\begin{array}{c}\text { NA/ST } \\
(0.11962) \\
\end{array}$ & $\begin{array}{c}\text { NA/ST } \\
(0.16804) \\
\end{array}$ & $\begin{array}{c}\text { NA/ST } \\
(0.22001) \\
\end{array}$ & $\begin{array}{c}\text { NA/ST } \\
(0.06403) \\
\end{array}$ & $\begin{array}{c}\text { NA/ST } \\
(0.15800) \\
\end{array}$ & $\begin{array}{c}\text { NA/ST } \\
(0.14429) \\
\end{array}$ & $\begin{array}{c}\text { NA/ST } \\
(0.19752) \\
\end{array}$ \\
\hline PbOviD102 & 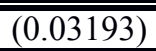 & (0.02964) & (0.00018) & $\overline{(0.00610)}$ & 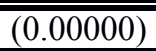 & (0.00018) & (0.00646) & $\overline{(0.05340)}$ & (0.00000) & (0.00464) & (0.00000) & 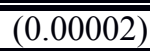 \\
\hline
\end{tabular}




\section{Electronic Supplementary Material}

Influence of hydrodynamic connectivity on the genetic structure and gene flow of the common pandora Pagellus erythrinus

Anna Rita Rossi, Paolo Colangelo, Léo Berline, Elisa Angiulli, Giandomenico Ardizzone, Chiheb Fassatoui, Luciana Sola

Online resource 3: POWSIM simulations to assess the statistical power of microsatellite loci to differentiate populations at varying levels of expected FST. Results of X2 and Fisher's exact tests for the proportion of simulations out of 1000 significant with a critical value of 0.05 .

\begin{tabular}{lllll}
\hline Expected $F_{S T}$ & $\mathrm{~N}_{e}$ & $\mathrm{t}$ & $X^{2}$ test $(\%)$ & Fisher's test $(\%)$ \\
\hline 0.0005 & $1.000 / 5.000 / 10.000$ & $1 / 5 / 10$ & $49.7 / 52.7 / 50.5$ & $47.5 / 50.3 / 49.3$ \\
0.0010 & $1.000 / 5.000 / 10.000$ & $2 / 10 / 20$ & $95.5 / 94.9 / 95.7$ & $90.4 / 91.8 / 90.9$ \\
0.0025 & $1.000 / 5.000 / 10.000$ & $5 / 25 / 50$ & $100 / 100 / 100$ & $100 / 100 / 100$ \\
0.0050 & $1.000 / 5.000 / 10.000$ & $10 / 50 / 100$ & $100 / 100 / 100$ & $100 / 100 / 100$ \\
0.0100 & $1.000 / 5.000 / 10.000$ & $20 / 100 / 200$ & $100 / 100 / 100$ & $100 / 100 / 100$ \\
\hline
\end{tabular}




\section{Influence of hydrodynamic connectivity on the genetic structure and gene}

\section{flow of the common pandora Pagellus erythrinus}

Anna Rita Rossi, Paolo Colangelo, Léo Berline, Elisa Angiulli, Giandomenico Ardizzone,

Chiheb Fassatoui, Luciana Sola

\section{Online resource 4}

Discriminant Analysis of Principal Component (DAPC). The obtained graph represents the individuals as dots and the groups (identify by k-means) as different colors. Eigenvalues of the discriminant axes (DA) and the comulative variances of the PC axes used are displayed in insets.

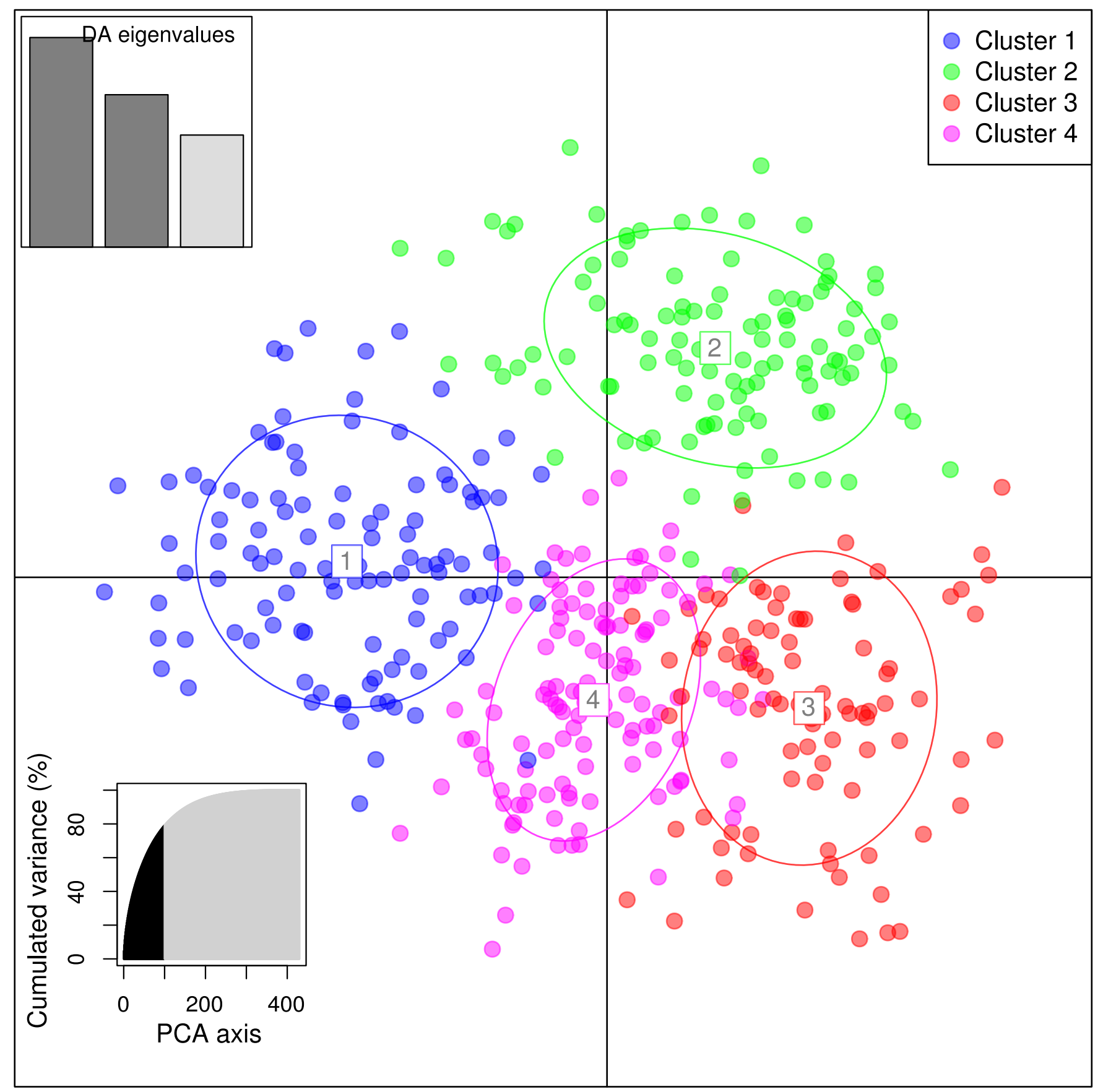




\section{Electronic Supplementary Material}

\section{Influence of hydrodynamic connectivity on the genetic structure and gene flow of the common pandora Pagellus erythrinus}

Anna Rita Rossi, Paolo Colangelo, Léo Berline, Elisa Angiulli, Giandomenico Ardizzone, Chiheb Fassatoui, Luciana Sola

\section{Online resource 5:}

Mean connection time (MCT) among pair of sites. Only MCT below 200 days were considered. NaN indicates MCTs above 200 days

\begin{tabular}{|c|c|c|c|c|c|c|c|c|c|c|c|c|}
\hline & To & & & & & & & & & & & \\
\hline From: & AN & BA & JO & EN & FM & GA & VM & SN & $\mathbf{A L}$ & BZ & LM & $\mathbf{Z A}$ \\
\hline AN & - & 115.343 & $\mathrm{NaN}$ & $\mathrm{NaN}$ & $\mathrm{NaN}$ & $\mathrm{NaN}$ & $\mathrm{NaN}$ & $\mathrm{NaN}$ & $\mathrm{NaN}$ & $\mathrm{NaN}$ & $\mathrm{NaN}$ & $\mathrm{NaN}$ \\
\hline BA & $\mathrm{NaN}$ & - & 199.327 & $\mathrm{NaN}$ & $\mathrm{NaN}$ & $\mathrm{NaN}$ & $\mathrm{NaN}$ & $\mathrm{NaN}$ & $\mathrm{NaN}$ & $\mathrm{NaN}$ & $\mathrm{NaN}$ & $\mathrm{NaN}$ \\
\hline JO & $\mathrm{NaN}$ & $\mathrm{NaN}$ & - & 148.421 & 120.661 & 105.241 & 59.278 & $\mathrm{NaN}$ & $\mathrm{NaN}$ & $\mathrm{NaN}$ & $\mathrm{NaN}$ & $\mathrm{NaN}$ \\
\hline EN & $\mathrm{NaN}$ & $\mathrm{NaN}$ & 180.97 & - & 113.199 & 127.119 & 179.191 & 112.058 & 191.018 & $\mathrm{NaN}$ & $\mathrm{NaN}$ & $\mathrm{NaN}$ \\
\hline FM & $\mathrm{NaN}$ & $\mathrm{NaN}$ & 156.431 & 74.65 & - & 102.64 & 170.539 & 145.889 & $\mathrm{NaN}$ & $\mathrm{NaN}$ & $\mathrm{NaN}$ & $\mathrm{NaN}$ \\
\hline GA & $\mathrm{NaN}$ & $\mathrm{NaN}$ & 140.907 & 94.269 & 55.141 & - & 123.078 & $\mathrm{NaN}$ & $\mathrm{NaN}$ & $\mathrm{NaN}$ & $\mathrm{NaN}$ & $\mathrm{NaN}$ \\
\hline VM & $\mathrm{NaN}$ & $\mathrm{NaN}$ & 63.732 & 128.283 & 92.117 & 82.791 & - & $\mathrm{NaN}$ & $\mathrm{NaN}$ & $\mathrm{NaN}$ & $\mathrm{NaN}$ & $\mathrm{NaN}$ \\
\hline SN & $\mathrm{NaN}$ & $\mathrm{NaN}$ & 196.626 & 153.813 & 129.73 & 194.615 & & - & 53.295 & 130.72 & 194.761 & $\mathrm{NaN}$ \\
\hline $\mathbf{A L}$ & $\mathrm{NaN}$ & $\mathrm{NaN}$ & 182.998 & $\mathrm{NaN}$ & 186.644 & & 168.05 & 77.288 & - & 91.82 & 154.64 & $\mathrm{NaN}$ \\
\hline BZ & $\mathrm{NaN}$ & $\mathrm{NaN}$ & 134.09 & $\mathrm{NaN}$ & 167.053 & 161.51 & 108.496 & 249.425 & $\mathrm{NaN}$ & - & 103.632 & 184.872 \\
\hline LM & $\mathrm{NaN}$ & $\mathrm{NaN}$ & $\mathrm{NaN}$ & $\mathrm{NaN}$ & $\mathrm{NaN}$ & $\mathrm{NaN}$ & 160.144 & $\mathrm{NaN}$ & $\mathrm{NaN}$ & $\mathrm{NaN}$ & - & 119.735 \\
\hline $\mathbf{Z A}$ & $\mathrm{NaN}$ & $\mathrm{NaN}$ & $\mathrm{NaN}$ & $\mathrm{NaN}$ & $\mathrm{NaN}$ & $\mathrm{NaN}$ & $\mathrm{NaN}$ & $\mathrm{NaN}$ & $\mathrm{NaN}$ & $\mathrm{NaN}$ & 162.997 & - \\
\hline
\end{tabular}




\section{Electronic Supplementary Material}

Influence of hydrodynamic connectivity on the genetic structure and gene flow of the common pandora Pagellus erythrinus

Anna Rita Rossi, Paolo Colangelo, Léo Berline, Elisa Angiulli, Giandomenico Ardizzone, Chiheb Fassatoui, Luciana Sola

Online resource 6: Model comparison of the eight models. For each model the marginal likelihood estimated using the Bezier approximation is reported. The probability of each model was calculated following Beerli and Palczewski (2010)

\begin{tabular}{|l|c|c|}
\hline Model number & Bezier approximation & P model \\
\hline Model 0 & -7006182.17 & 0 \\
\hline Model 1 & -546114.82 & 0 \\
\hline Model 2 & -3788213.34 & 0 \\
\hline Model 3 & -349000.46 & 1 \\
\hline Model 4 & -3516744.21 & 0 \\
\hline Model 5 & -1262798.92 & 0 \\
\hline Model 6 & -442189.13 & 0 \\
\hline Model 7 & -1218611.85 & 0 \\
\hline
\end{tabular}

